\title{
Study on the Negroes' Cultural Otherness in I, Too, Sing America
}

\author{
Jun Luo
}

School of Foreign Languages, Zhaotong University, Zhaotong, China

Keywords: I, Too, Sing American, Negro, Cultural Otherness.

\begin{abstract}
Despite the singularity of I, Too, Sing American, few scholars and critics around the world have discussed much about the cultural divergences between the negroes and the whites in American society, fewer of them exemplified the humble position as well as the unfair treatment of the negroes through the subtle combination of his poetry with the unbearable experience of the Negroes and fewest of them on the negroes' cultural otherness in accordance with their understanding of this poem. To enrich the academic studies in this respect, this paper will elaborate this problem based on the cultural otherness in this poem.
\end{abstract}

\section{The Cultural Oneness of This Poem}

The poem I, Too, Sing America, has carried Hughes's meditation on African-American culture as exemplified below: "The very fact that Negroes do straighten their hair and try to forget their racial background and makes them different from white people..." [12] (Singh Amritjit, p36) That is because he has realized its importance as asserted in Turner's claim that "in many respects ...there could be a literary culture among Blacks". [13] (Turner, Darwin T., p201-210) Bearing this in his mind, he has even manifested that: "we younger Negro artist who create now intend to express our own individual dark-skinned selves without fear or shame..."[2] (Bone, Robert A., p65-94) In effects, he has also been thinking of the negroes' cultural otherness as implied in this poem even though it has been neglected for a long time.

\section{The Critical Inadequateness for This Poem}

Although this poem hasn't been paid immediate and adequate attentions to by either poetic critics or poetic readers upon its publication in spite of its abundance with thematic implications, few scholars including foreign scholars and domestic scholars have showed their academic interest in it from their respective perspectives as explained in the following two folds.

Firstly, despite the difficulty in finding out all the research findings of all foreign scholars, those of three authoritative scholars (Rampersad, Brooks and Hitchens) have been clarified in this essay to give a picture of the current studies in this regard.

Directly enough, Rampersad mentions this poem in The Life of Langston Hughes, VolumeI, 1902-1941) concerning his discussion of the poet's descriptive styles in the poem I, Too, Sing America and his closely-knit combination of this poem with the poet's growing experience and its valuable relevance to the negroes' lives by pointing out that "I, Too, Sing America is a sympathetic, yet clear-eyed portrait of one of America's most controversial writers that also manages to be a sweeping depiction of the black experience in this country and abroad during the first four decades of the 20th century". [10] (Rampersad, Arnold, p1005)

Unlike the studies of Rampersad, Brooks focuses on the Huges's personal persistence by arguing that "Hughes is simply not very vulnerable..."[4] (Brooks, Gwendolyn, p7) and Hughes's criticism of America as shown in this line "America never was America to me..."[4] (Brooks, Gwendolyn p9) in accordance with his sympathy for the epitomized Darker Brother in this poem.

Based on the doubt color plays an important role in his unhappiness, Hitchens finds out from this poem the same discriminant situation in his experience in white schools and classes when he suffers from vulgar abuses and discrimination caused by his intensive reading Hughes's poems. The 
empirical evidences convince him of Rampersad's idea "On each of the few occasions in his (Hughes's) life when his internal pressures proved too great to bear, the cause would be private rather than racial". [6] (Hitchens, Christopher, p22)

Secondly, relatively, Chinese scholars have made more study of Hughes' poems like Not Without Laughter (1930), Negro speaks of Rivers (1921), The Weary Blues (1926), and Fine Clothes to the Jew (1927) apart from I, Too, Sing America. Even the studies of Luo Liang-gong, Liu Li-hua, and Liu Wen seldom have been devoted directly to the interpretations of this poem in addition to the thematic analysis of Hughes's poems [8] (Liang-gong Luo, p25), the exploration of the correlation between Hughes's poems and his personal experiences[9]( Liu-hua Liu, p35-37), as well as Hughes's impact on American music like blues, Jazz as well as negro pop music in the articulation of his disappointment at American social reality [13](Wen Liu, p13).

Since it has been indicated that both foreign and Chinese scholars haven't dealt with the negroes' cultural otherness in their studies, this essay will make an exploration in this respect.

\section{The Analytical Device of This Poem}

Corresponding to the focus of this essay, the analytical device of this poem is the cultural otherness relevant to the exploration of the correlation between cultural selfness and cultural otherness in correspondence with the similar relationship between the whites' dominant culture and negroes' cornered culture based on the established theoretical elaboration to the term otherness that is not likely to shorten the conceptual and cultural distance [1](Balslev, Anindita Niyogi, p9) of intercultural communication owing to the difficulty in going across the cultural boundaries [1]( Balslev, Anindita Niyogi, p10) of a marginal culture and non-marginal culture regard less of their cultural otherness frequently referred as cultural barriers of cross-cultural communication. In this sense, this essay is likely to showcase that the cultural otherness may occur not only in cultural contexts but also in poetic contexts as typified in the poem to be analyzed in this essay.

\section{The Cultural Otherness of This Poem}

\subsection{The Cultural Otherness between the Negroes' Uniqueness and the Whites' Sameness}

In the mind of cultural critics, poets have been transmitting not only cultural information but cultural attitudes and values that reflect their views of the world and shape those of their readers just as what to be analyzed below in the first stanza of I, Too, Sing America regarding Hughes's attitude towards and value on the cultural otherness of the negroes culture manifested in the mutual resistance and dependence between the uniqueness of the negroes and the sameness of the whites in their competitive existence.

Like the darker brother's pursuit of recognition in his choices of "...laugh, eat well and grow strong"[11] (Rampersad, Arnold, p46) while being sent to eat in the kitchen, the negroes' culture also makes its way to its cultural existence while being discriminated by whites' culture. Taken the cultural otherness into account, it can be evidently felt that what lies behind the whites' dislikeness of the darker brother is not just a problem of interpersonal communication but also a profound reflection of the cultural recognition between the former culture and the latter culture as mentioned above where one of them has been trying to acquire its dominance by depriving the other of dependence as shown in the exploitation of the negroes' uniqueness and the acquisition of the whites' sameness.

In line with the theoretical insight of cultural otherness, the existence of one culture is located in either the cultural awareness of egoistic recognition or that of another recognition. Similarly, what happens in the cultural context of this stanza seems to indicate that the cultural sameness of whites' culture counts much on the reluctant recognition of the negroes' cultural uniqueness that has been forced to pretend to be voluntary to accept everything as they have been required and expected by the former at the cost of the disappearance of their own cultural dignity by means of keeping silence, wearing smiles and taking them as brothers generously while hiding their instinctive unwillingness.

In this way, the negroes' disadvanateous culture has nothing to do but make a concession for the 
whites' advantageous culture at the risk of making their own cultural uniqueness lost in the oblivion of cultural history to give its way to the cultural sameness of whites' culture owing to its inadequate ability to subvert the cultural inconsistencies between them despite its belief fact that the contemporary unfavorableness of its passive recognition of the whites' cultural sameness is likely to be subverted when it grows strong enough before having an opportunity for it to show its cultural uniqueness in the future. To be short, the cultural discrimination the whites has been holding to the negroes in this stanza has turned out to be an appropriate example to show the hegemonic sameness of the whites' culture to deaden the uniqueness of the negroes' culture or its own cultural otherness due to its own autonomous cultural recognition by means of isolating the cultural decencies of the latter.

\subsection{The Cultural Otherness between the Negroes' Oneness and the Whites' Wholeness}

In multicultural contexts, it seems to be true that the oneness of each culture carries its own attitude towards the wholeness of another grounded on the cultural unsameness in their respect lives, wisdom as well as value just as what has been exemplified in the second stanza of this poem regarding the cultural confrontation between the negroes' cultural oneness and the whites' cultural wholeness, for although the former has been trying its best to avoid being dominated, marginalized or replaced by the dominant or hegemonic qualities of the latter, it has turned out to be inevitable that the former seems to be unable to run away from being cornered or isolated by the latter.

It is for this reason that Hughes has released his cultural anger at the domination or manipulation of the whites' culture in the second stanza of this poem and his strong desire to maintain and develop the cultural oneness of the negroes' culture in the articulation of his cultural attitudes in the lines quoted below "...Nobody'll dare Say to me, / 'Eat in the Kitchen'"(Rampersad, Arnold, p46) in the future. Of course, this emotional release is also an expression of his cultural resistance against the cultural domination of the whites' culture caused by the sound bitterness the negroes have been suffering from the whites' prejudice. In the sense of cultural independence, it is reasonable for them to "reject the protestant ethic" [4] (Bone, Robert A., p75) of the whites and make great efforts to remove the whites' ideological manipulation through cultural marginalization or isolation.

What is worth more attentions is the word "Dare" in those lines that have been characterized with the decisive determination that anticipates the rapid growth and tremendous impacts of the negroes' culture driven by the cultural discrimination of the whites' culture in the future on the road to the protection of its cultural dignity through the maintenance of its special qualities and subversion the cultural hegemony of the whites despite the reluctant tolerance in the past and at present, for it appears to be evident in The Declaration of Independence that the black people have the rights of "life, liberty and the pursuit of happiness." [15] (Wei-ren Wu, p37).

To the extent of multicultural communication, what has been echoed from this word "Dare" is the ambivalent and relevant correlation between the oneness of the negroes' culture and the wholeness whites' culture in the form of cultural competition and cooperation in the process of mutual communication and introduction owing to their mutual dependence to show their respective superiority to each other. It is unwise for either of the two cultures to replace the oneness of one culture, i. e, its cultural otherness with the wholeness of the other in a violent or barbarous way, which is true of the whites' culture.

\subsection{The Cultural Otherness between the Negroes' Unselfishness and the Whites' Selfishness}

Despite the juxtaposition in this title, it ought to figure it out that the cultural selfishness and unselfishness are the intrinsic qualities of a given culture and the remarkable difference between them lies in the respective manifestations of them at different stages just as the sharp contrast between the responses of the dark brother in the first stanza and the third stanza.

In the first stanza, the dark brother appears to be careless for the cultural isolation or even cultural crisis when he has been asked to eat in the kitchen in spite of his insatiation with his masters out of his contemporary concealment of his indomitable will in an unselfish way while the white master being treated as selfish to avoid the unnecessary disgraces in the presence of guests.

However, in the third stanza, this dark brother has been awake from the segregation of his cultural grace, identity and dignity by the cultural prosecution of the whites and begin to protect their cultural 
existence against deconstruction and destruction through their autonomous construction as seen in his pride in his negritude as much as the quintessence of his own culture and the unstated recognition of the other witnessed in the cultural guilt of his masters as shown in the two words "beautiful"and "shamed " of this line "...They'll see how beautiful I am/ And be shamed " [11] (Rampersad, Arnold, p46), to the effect that they have achieved "the affection of the Black America" [7](James, A. Emmanuel, p179). The cultural context changed, what has been dealt with the negroes is also true of the whites.

In short, what has been indicated in this textual example is that the cultural otherness about the negroes' unselfisheness and the whites' selfishness has been noticed in the transition of the dark brother's earlier unselfishness to his later selfishness ought to be regarded to be the interaction of both his cultural sopopsism rooted in his cultural inferiority and the cultural altruism shaped by his cultural priority exemplified in whites' admiration for his beauty.

\subsection{The Cultural Otherness between the Negroes' Unselfness and the Whites' Selfness}

In response to the dark brother's better knowledge of his cultural dignity based on the cultural discrimination he has been suffering from the unfair treatment he has received in his contact with the whites, he begins to have a thorougher understanding of his unselfness owing to the stimulation of the cultural otherness of the whites as has been shown in the last line" I, too, am America [11] (Rampersad, Arnold, p46)"of this poem.

Taken into consideration the cultural understanding of this line, it ought to be crucial for the dark brother of this poem, for it stands for the thorough retrospection he has gained after experiencing the discriminant assessment of the whites who have been serving as the otherness of him before his profound understanding of his selfness from unselfness.

In this sense, the cultural otherness in this poem ought to be felt in the epistemological or ideological enhancement of the dark brother because of his ontological understanding of his selfness through the illuminative stimulation of the other and the interaction between his ontological selfness and his externalized unselfness that he has dug out from the critical or discriminant observation of the other in the cultural confrontation of his own awareness of his selfness with his unselfness that has been unknown to him, for he tends to be unable to have a good understanding of the other that have been affecting his existence and his overall understanding of himself due to the agnostic qualities of the external things that are likely to be served as the other in the very existence of his own life.

Therefore, it is necessary to be admitted that the qualitative highlight of a given culture lies in its participants' overall understanding of both their unselfness and their selfness after either a sudden or a sustainable perception of their own existence. What has been articulated herein is true of not only the retrospection of the unselfness of the negroes but also the reflection of the selfness of the whites in the ideological competition between them either in an active way or in a passive way. This is where the cultural otherness of this poem locates.

\section{Conclusions}

To sum up, based on the analysis made of above in four respects, it can be concluded that the cultural otherness of the negroes as manifested in this poem has turned out to be a substantial existence in their epistemological enhancement of their subjective existence and objective existence enlightened by both the intersubjective and interobjective interaction between the negroes and the whites in their respective cultural contexts. Owing to the limited length of this essay, it is impossible to explain everything related to the cultural otherness put forward in this essay in details, so the more detailed and profounder studies in this respect will be expected to come out in future studies.

\section{References}

[1] Balslev, Anindita Niyogi. 1999.Cultural Otherness: Correspondence with Richard Rorty (Second Edition). Atlanta: Scholars Press Atlanta, p:9-10.

[2] Bone, Robert A. "The Harlem School," in his The Negro Novel in America. Yale University Press. 
1998, p: 65-94.

[3] The Negro Novel in America. Yale University Press, revised edition, 1965, p:75.

[4] Brooks, Gwendolyn. "The Darker Brother." The New York Times Book Review. October 12, 1986, p:7-9.

[5] Dekle, Bernard. "Langston Hughes: Dedicated Negro Poet", in his Profiles of Modern American Authors. Charles E. Tuttle, 1969, p:125-130.

[6] Hitchens, Christopher. "Whiteman's Darker Brother." The Observer. January 18, 1987, pp.22.6

[7] James, A. Emmanuel. Langston Hughes. Twayne, 1967, p:179.

[8] Liang-gong Luo. 2005 (4). On the Humor of Langston Hughes, Foreign Literature Studies, p: 25-31.

[9] Liuhua Liu. 2000. Langston Hughes and His Dream, Journal of Mudanjiang Normal University (Philosophy Social Science Edition), p: 35-37.

[10] Rampersad, Arnold. A Review of "The Life of Langston Hughes, Vol. I, 1902-1941: I, Too, Sing America," Kikus Review. Vol. LIV, No. 13, July 1, 1986, p:1005.

[11] The Collected Works of Langston Hughes (Volume (1): The Poems: 1931-1940). Columbia: University of Missouri Press.2001, p:46.

[12] Singh, Amritjit. "'When the Negro Was in Vogue' The Harlem Renaissance and Black America," in his The Novels of the Harlem Renaissance. Twelve Black Writers, 1923-1933, The Pennsylvania State University Press.1976, p: 1-39.

[13] Turner, Darwin T. "The Harlem Renaissance: One Facet of an Unturned Kaleidoscope," in Toward a New American Literary History: Essays in Honor of Arlin Turner, Louis J. Budd, Edwin H. Cady, and Carl L. Anderson, eds., Duke University Press.1980, p:195-210.

[14] Wen Liu. 2007. Sorrows and Promises: The American Dream in Langston Hughes's Poems, Social Scientist, p:13-16.

[15] Weiren Wu. 2002 (8). History and Antholohy of American Literature, Vol. 1, Beijing: Foreign Language Teaching and Research Press, 2002, p:46. 